\title{
Socially-oriented economy as part of the macroeconomic development system
}

\author{
Fatima Dakhaeva ${ }^{1,2^{*}}$, and Azalea Amirova ${ }^{1,2}$ \\ ${ }^{1}$ Chechen State University, st. Sheripova 32, Grozny, 364024 Chechen Republic, Russia \\ ${ }^{2}$ Grozny State Oil Technical University named after academician M.D. Millionshchikova, Kh.A. \\ Isaeva, 100, Grozny, 364905, Chechen Republic, Russia
}

\begin{abstract}
This article analyzes the current situation in the world economy, which includes socio-economic tools, innovative and technical mechanisms. The stable economy of the region is based on social sustainability and a favorable economic climate to attract investment and highly qualified personnel. Develop human resources, investment in the educational sphere, and the development of a "knowledge-based economy" is a priority for the Chechen Republic. Social and economic policy is a set of measures to create favorable conditions for the development of society, taking into account the provision of an appropriate level of economic efficiency and social justice in all spheres of human life. In conditions of geopolitical rivalry, it is necessary to increase the competitiveness of the economy also through new technologies.
\end{abstract}

\section{Introduction}

Social policy is the policy of the state aimed at mitigating inequality in the distribution of income and property, smoothing out contradictions between participants in the market economy and the incidence of social conflicts on the economic soil.

A lot of planning history of the development of social structures of various states is being reconsidered, the position on the mutually complementary role of economic and social court systems is confirmed [2].

Regardless of what kind of people are, economic progress is a consequence of the implementation of successful social policy and public material welfare, the satisfaction of the package social services. The key indicator of the level of development of the eco-mycosocial sphere is the novelty of the adopted judicial measures and the scale of improvement of the structure of the economy, and the urgency, timeliness and quality of the quality of the process.

Under the guidance of the Head of the Chechen Republic, I am doing a lot to establish social stability in the region. This refers to the minimum wages, scholarships, pensions, benefits, reduction of the unemployment rate in the region, support of socially unprotected citizens, support for those in need, assistance in employment - they are prioritized guidelines in the activities of the Chechen leadership [5].

\footnotetext{
* Corresponding author: dahaevaf@mail.ru
} 


\section{Definition of "social policy" in society}

The social stability and welfare of the country depend on the performance of the decisions put to the problems in the front of the state system. The main features of the socially oriented policy of the state are stability, welfare of the population, sustainable processes in the social and economic sphere of society. As a result, social sustainability can be characterized as providing with the help and social protection of all segments of the population, creating a stable and promising development in the areas of education, health care, and social protection.

After the Second World War, the economic theory of the social court emerged, when it was necessary to pursue appropriate policy in the field of the financing, financing of social sectors and programs, loans, investments.

The social court establishes the rules of conduct in the field, mechanisms of operation and control to achieve the following goals [1]:

1. Support and development of the local economy to ensure the economic safety of the country,

2. Implementation of the pricing policy in the interests of the giver and the employee,

3. Social protection and support of the population,

4. Carrying out a policy of distribution to ho do in the city.

Social policy is a part of economic policy and is implemented through the development of material and spiritual benefits of the population, the ultimate goal of which is to improve the welfare citizens of the country.

One of the directions of social policy is the state court. to vulnerable segments of the population through the social security system and the minimization of inflationary depreciation of income and savings.

The redistribution of households to the population goes through the budget through a differentiated taxation. The state redistributes income by paying social transfers, introducing minimum rates for wages, as well as changes in prices set by the market. On the other hand, redistribution going inside the community leads to a decrease in economic efficiency, which the American eco nist A. O uken compared with the "leaky bucket" [2]. In view of the fact that when redistributing up to ho do, it is necessary to know the measure of the increase in the overlap, as well as the social redistribution, a shift to one side or the other can lead to a decrease in labor supply and an increase in the shadow sector. The main directions for the creation of social programs are [10]:

1. Support for the average living level of towns with a low level of income,

2. To reduce the level of inequality in society,

3. Submission of reports on the use of budgetary funds,

4. Provision of accessible social assistance,

5. Strengthening social support for individual citizens in need.

\section{State programs in a socially oriented society}

The social and economic system of the state court, which is oriented towards the population: it provides all its needs and socially protects it, forms such a society, at which all its representatives strive for eco nomic enrichment, which leads to enrichment of the state as a whole. For this scheme to work, it is necessary observance of several rules [7]:

A. Labor distribution and the growth of business in employment must be explained by the reasons for the improvement of the eco-myco-social situation of the population to the extent required; 
B. Minimum differentiation of incomes in economic subjects in the measure of their consumption, which determines the results of the entrepreneurial labor activity of the population.

Modern social policy is divided into hard and soft policies:

The hard variant presupposes the reduction to the minimum value of the tax on income of the population for the activation of entrepreneurial activity; temporary suspension, or canceling the indexation of social wages, toughening the conditions for obtaining a social package (benefits). In general, this is a decrease in the consumption of the state for the spheres of social security to stimulate the private sector of the country and increase its income [4]. The structure of a strict policy acts for the benefit of the state and the development of economic growth and does not always take into account the opinion of the social group; at the same time, the implementation of this strategy into the current political life of the country the underwhelming of society is being exploited.

A mild social policy on the contrary expands social programs, for example, increases taxes for financing programs, thereby contributing to the improvement of welfare a hundred years for the birth. However, this policy faces some difficulties in the economic sphere of the state. Firstly, the permanent growth of the location as a way to the social spheres of the country restrains the entrepreneurial sphere, thanks to which additional financing appears. in the state budget [6]. Secondly, any redistribution of a person's income with the help of a tax in practice turns out to be little effective, since the level of inequality among citizens decreases insignificantly. The internal structure, goals and objectives of social policy also depend on the economic potential of the country, the demographic situation, the pace and nature of the growth of industrialization in society. welfare state and social institutions, etc. Thus, the process of the country's social and economic path depends on the cycle and a number of political leaders, which were formed by history, on the to $\mathrm{m}$, its culture, tradition, etc.

Despite the pandemic over the last 6 months of 2020, positive dynamics is observed in a number of indicators of social and economic development in the Chechen Republic [7].

Thus, the volume of loaded goods is 51.8 billion rubles. or $133.7 \%$ of the level of the natural period of 2019 ( 38.7 billion rubles) .Volume of agricultural production - 6.7 billion rubles. or $100.4 \%$ ( 6.6 billion rubles).

Despite the lifting of restrictive measures, unemployment continues to grow, and today it is $20.5 \%$ (130 thousand people), an increase of $12.4 \%$, in March 2020 . was $8.1 \%$ (50.5 thousand people). The turnover of retail trade decreased by $10.8 \%$ and amounted to 60.4 billion rubles (it was 66.1 ), 15.8\% less than the cost of paid services, the volume of which with the cost of 20.9 billion rubles against 24.2 billion rubles.

A slight decrease is also observed in the construction sector. The volume of construction work decreased by $2.9 \%$ to 12.0 billion rubles (it was 14.4 ) [6].

Nevertheless, it can be noted that there are a lot of construction projects at the stage of completion in the city center and on the periphery. Residents, who threw the republic during the pandemic and then exploded, were surprised at how purposefully the Head of the Republic implements the strategy of social and economic development of the region. in spite of the external economic crisis.

The economic policy in the social sphere is based on the introduction of state programs for the protection of the population: additional pension payments, paid maternity leave, subsidies in case of loss of rmiltsa, finanso va i support for the time of loss of labor. What is typical in the current situation in the world economy, when factories and corporations with a long history are closed due to the pandemic, world brands are closing their shops all over the world, people are being cut, gardens and schools are not working [9].

Over the past years, the growth of the quality of professional education in the region has not reached a new level due to the constant attention to this sphere of the Head of the 
Republic, Ramzan Ahma Tovich made the formation of a priority sphere, I understand that the good fortune of the Chechen people and the prosperity of the republic depend on this. Over the past three years, 50 new schools have been built in the republic. In total, there are more than 470 public educational institutions in the region, in which 267 thousand schools are enrolled. The sphere of professional education is represented by 4 universities and 24 colleges and technical schools [7].

The competitive advantage of any region and economy is ensured by the development of all its potential. For this reason, ensuring the stable economic growth of the Chechen Republic, as a rule, belongs to the sphere of professional education [8]. The Chechen Republic is a leader in terms of financial investment in the spheres of science and education. By this time, the region takes the first places in the development of human potential among the regions in the North Caucasus Federal District. Thus, on average in the Russian Federation, the share of finan cials in the education sector is $4 \%$, in our region this indicator is $15 \%$.

Development of the social and economic level of the Chechen Republic in 2012-2025 takes place at five this stage (as a result of many levels of modernization) [8]:

The first stage (2012-2013) was based on the realization of the competitive advantages that the economy of the Chechen Republic enjoys in traditional spheres. At this stage, it was necessary to create conditions for the development and preparation for the implementation of investment projects, to launch business legitimation, to create conditions for increasing safety and security. the attractiveness of the region.

The second stage (2014-2015) was based on the creation of a system of innovation development and provision of conditions for improving the quality of life of the population of the region;

The third stage (2016-2017) - technological work is being created to ensure the transition of the economy to a new mode of innovation development at the next stage;

The fourth stage (2016-2020) is a breakthrough in increasing the competitiveness of the economy on the basis of transition to a new model of development, improvement of the quality of human potential and the civil environment;

The fifth stage (2021--2025 and beyond) will be aimed at fixing the new development model and achieving the position of the subject with high rates of development. All of the above will ensure a stable social and economic development of the Chechen Republic [7].

\section{Conclusions}

Summing up, we can say that social and economic policy is a combination of measures to create favorable conditions for the development of society with due regard for to the right level of economic efficiency and social justice in all spheres of human life.

The Chechen Republic has a large resource base, which can be used to produce conn utensils that are capable of production, but for this it is necessary to fly about the workload associated with the need for a high-quality staff and not enough staff Wed units

The strategic vision of the Chechen Republic by 2025 according to the written regulation: "The Chechen Republic 2025 is a dynamically developing subject of the Russian Federation, with high rates of economic quality of life, achieved through harmony in human development, economy and infrastructure ". The main goal of the leader of the region Ramza na Akhmotovich Kadurov is to become one of the leading regions in Russia in terms of GRP (domestic regional product) per capita, which is It calls to achieve growth in the social and economic sphere of the population and bring the region to high interregional ratings. The main objectives for 2025 are to achieve such a level of indicators of social and economic development, which are characteristic for highly developed regions 
in with innovative eco no mico. For this, we need a systematic approach in the implementation of strategic development goals.

\section{References}

1. Civic Code of the Russian Federation.

2. Law of the Russian Federation on July 17, 1999 No. 178-FZ "On state social assistance"

3. Law of the Russian Federation of December 29, 2006 No. 256 "On additional measures ofstate support for families with children"

4. Law "On Approval of the Strategy of Social and Economic Development of the Chechen Republic until 2025"

5. Law of the Chechen Republic of July 20, 2018 No. 38-RZ "On the forecasting and planning of social and economic development of the Chechen Republic"

6. Kantsero in R.A., National interests of safety, 49 (2019)

7. Government Decree of the Russian Federation of March 30, 2018 No. 364 "Promotion of employment of the population"

8. Government decree from 15a of 2014, No. 295 "Development of education" for 20132020

9. Uruno in A. AND, Integration and Economic Growth, Graal, 424 (2020)

10. A.V. Balabanova, Macro economica. Mechanisms for increasing the quality of growth, Higher. school, 373 (2019)

11. E. V. Ogurtsova, O. Yu Chelnokova, Economics. Management. Pravo, 3-9 (2020) 